Article

\title{
Effects of a Wildfire on Selected Physical, Chemical and Biochemical Soil Properties in a Pinus massoniana Forest in South China
}

\author{
Li Xue *, Qiujing Li and Hongyue Chen \\ College of Forestry, South China Agricultural University, Guangzhou 510642, China; \\ E-Mails: liqiujing0528@sina.cn (Q.J.L.); chenhongyuetz@126.com (H.Y.C.) \\ * Author to whom correspondence should be addressed; E-Mail: forxue@scau.edu.cn; \\ Tel.: +86-20-38297160; Fax: +86-20-85280256.
}

Received: 1 September 2014; in revised form: 14 November 2014 / Accepted: 21 November 2014 / Published: 25 November 2014

\begin{abstract}
Pinus massoniana forests bordering South China are often affected by wildfires. Fires cause major changes in soil properties in many forest types but little is known about the effects of fire on soil properties in these P. massoniana forests. Such knowledge is important for providing a comprehensive understanding of wildfire effects on soil patterns and for planning appropriate long-term forest management in these forests. Changes in soil physical properties, carbon, nutrients, and enzymes were investigated in a $P$. massoniana forest along a wildfire-induced time span consisting of an unburned soil, and soils 0 , one, four, and seven years post-fire. Soil $(0-10 \mathrm{~cm})$ was collected from burned and unburned sites immediately and one, four, and seven years after a wildfire. The wildfire effects on soil physical and chemical properties and enzyme activities were significantly different among treatment variation, time variation, and treatment-by-time interaction. Significant short-term effects on soil physical, chemical, and biological properties were found, which resulted in a deterioration of soil physical properties by increasing soil bulk density and decreasing macropores and capillary moisture. Soil $\mathrm{pH}$ increased significantly in the soil one-year post-fire. Carbon, total nitrogen $(\mathrm{N})$ and phosphorus $(\mathrm{P})$, and available $\mathrm{N}$ and $\mathrm{P}$ increased significantly immediately and one year after the wildfire and decreased progressively to concentrations lower than in the unburned soil. Total potassium $(\mathrm{K})$ and exchangeable $\mathrm{K}$ increased immediately after the wildfire and then continuously decreased along the burned time-span. Urease, acid phosphatase, and catalase activities significantly decreased
\end{abstract}


compared to those in the unburned soil. In fire-prone P. massoniana forests, wildfires may significantly influence soil physical properties, carbon, nutrients, and enzyme activity.

Keywords: carbon; enzymes; nutrients; physical properties; Pinus massoniana forest; soils; wildfire

\section{Introduction}

Fire is an important disturbance factor in many terrestrial ecosystems [1]. Warming trends and recurring droughts increase the tendency of forest wildfires to occur [2-4]. Fire can lead to important changes in the properties of forest soils [5], which support critical processes such as hydrologic and biogeochemical cycling [6]. There are two basic types of forest fires: prescribed (controlled) fires and wildfires [7]. Prescribed burning of naturally accumulated forest floor or slash following tree harvest is a standard practice to reduce fuel levels. In contrast, wildfires generally occur in the presence of an abundant and dry fuel load and, thus, can be very severe [7], particularly where a heavy and dry fuel bed is present that can lead to combustion temperatures of up to $500-700{ }^{\circ} \mathrm{C}$ at the soil surface $[8,9]$. Because they consume soil organic matter (SOM), fires have detrimental impacts on soil physical properties, including increased bulk density [5,10], reduced soil porosity, and decreased water storage capacity $[11,12]$.

Fires can decrease the total amount of nutrients on site through losses from volatilization, smoke, ash transport, leaching, and erosion [10,13]. Soil $\mathrm{pH}$ has been found to increase because of the release of alkaline ions from production of potassium $(\mathrm{K})$ and $\mathrm{Na}$ oxides, hydroxides, and carbonates in the ash [14] and also organic acid denaturation with heating [12]. The main reasons for increased nutrient availability are the generation of ashes and increased mineralization. Heating of SOM usually gives rise to ash with different properties, depending on fire severity, whereas increased $\mathrm{pH}$ values may increase nutrient availability (e.g., the availability of some micronutrients like $\mathrm{Fe}, \mathrm{Mn}$ or $\mathrm{Zn}$ decreases with increasing $\mathrm{pH}$ ). However, fires may also contribute to decreased nutrient availability in the longer term because nutrients released from organic matter and microbial biomass are likely to be removed from the ecosystem by leaching and runoff $[15,16]$.

Post-fire recovery of soil nutrients is largely limited by microbial activity [17]. Because high-intensity fires can partially sterilize the surface soil [18], assessing soil microbial activity can be conducted through soil enzyme analysis [19]. Soil enzymes reflect microbial activity important for carbon, nitrogen $(\mathrm{N})$, and phosphorus $(\mathrm{P})$ cycling [20].

Fire's role in the terrestrial carbon cycle and nutrient dynamics have been extensively investigated in both natural and plantation forests in boreal and temperate regions, as well as for slash-and-burn agriculture in tropical forests [21-28]. However, many uncertainties remain in subtropical forests. As the impacts of fire on soils can be highly variable [6,29], it is important to understand how fire impacts on soil carbon and nutrients in subtropical forests to maintain soil fertility in those forests that have experienced fires.

Pinus massoniana is a fast-growing tree species with rich rosin, which is widely distributed in southern China [30], and has the greatest area and stored volume among the conifer species of 
China [31]. Wildfires are historically a major threat for this forest species. In Dongyuan, Southern China, natural forest wildfire events are prone to occur in the spring, characterized by relatively high temperatures and low relative air humidity. March comes after a period of little rain and lower temperatures, lasting from November to February, which supports the production and availability of a considerable fuel mass. In addition, acid soils limit microbial activity, resulting in an accumulation of litter on the forest floor [2,32,33]. Despite P. massoniana forests being fire prone, little is known about the effects of wildfires on properties of their soils. This information is critical for long-term planning and management of these forests.

Knowledge of soil fertility changes following wildfires is relatively small because of the lack of suitable comparable control sites and/or lack of pre-fire data. Hence, the effects of wildfire on soils are usually assessed after the fact using nearby forests as controls [6,34-36]. A wildfire burned through approximately half (3/7) of a P. massoniana forest in Dongyuan County, Guangdong province, China in March 2006. This allowed us to establish unburned and pre-burned plots in this P. massoniana forest after the wildfire for studying soil change in March 2006. This study aimed to study the impacts of a wildfire on (1) soil physical properties including soil bulk density, porosity, and capillary moisture; (2) soil carbon and N, P, and K and (3) activities of urease, acid phosphatase, and catalase during seven years in a $P$. massoniana forest by comparing burned with unburned adjacent soils.

\section{Material and Methods}

\subsection{Site}

The study site $\left(23^{\circ} 44^{\prime} \mathrm{N}, 114^{\circ} 42^{\prime} \mathrm{E}\right)$ is located in Dongyuan County, Giangdong province, China, which has a typical hilltopography with a northwesterly aspect and a slope of $35^{\circ}$. The climate is characterized by long hot summers, high humidity, and mild winters. The mean annual temperature is $20{ }^{\circ} \mathrm{C}$, and the mean annual precipitation is $2142 \mathrm{~mm}$, most of which occurs from April to June. A wildfire occurred in a $P$. massoniana forest in March 2006, and all tree crowns, understory vegetation and litter in part of this forest ( $3 \mathrm{ha}$ ) were completely burned. The blackened soil surface after the wildfire indicated that the heat generated during the burn was insufficient to completely consume the litter at the soil surface, suggesting that the fire was likely of moderate severity. The overstory vegetation in the unburned part was characterized by a $P$. massoniana forest with a mean stem diameter at breast height of $13.5 \mathrm{~cm}$ and a mean tree height of $11.0 \mathrm{~m}$ in March 2006. The understory vegetation in the unburned area consisted primarily of Dicranopteris dichotoma (Thunb) Bernh.), Rhodomyrtus tomentosa (Ait.) Hassk.), and Baeckea frutescens L. In March 2007, the understory vegetation in the burned area consisted primarily of Microstegium vegans (Need ex Steud., A. Camus), Miscanthus sinensis Andress, and Dicranopteris dichotoma (Thunb) Bernh. The soil is classified as Ultisols with strong acidity and is more than $1 \mathrm{~m}$ deep.

\subsection{Methods}

The study covered a period of 7 years, starting in March 2006, and ending in March 2013. Three replicate burn and unburned control sites were established, each averaging 0.5 ha. The litter was removed in the unburned plots, and the charred debris and the ash layer were removed in the burned plots, and 
then soil samples were collected from the upper $10 \mathrm{~cm}$ at 8 randomly located points in each plot. The burned and unburned soils were sampled one to two days and at 1, 4, and 7 years after the wildfire. Soil cores with a volume of $100 \mathrm{~cm}^{3}$ each were collected using a steel ring knife.

To measure soil physical properties, the fresh weight $\left(\mathrm{m}_{0}\right)$ of each soil core in one of the steel ring knives was weighed using a digital balance. Each core was placed in a water tray until the whole porosity of the soil was fully saturated with water (about 12 hours) and then was weighed immediately to obtain $\mathrm{m}_{1}$. In order to remove non-capillary water from the soil, the core was placed in a dry tray for 2 hours and was weighed again to obtain $\mathrm{m}_{2}$. Next, the core was placed in a dry tray for another 24 hours to continuously remove water and was weighed again to obtain $\mathrm{m}_{3}$. Finally, the core was oven-dried at $105{ }^{\circ} \mathrm{C}$ for 48 hours and weighed to obtain $\mathrm{m}_{4}$.

Soil water content $(S, \%)$, saturated water content $\left(S_{W}, \%\right)$, capillary moisture capacity $\left(C_{W}, \%\right)$ that is quantified in the field by the capacity of the unsaturated aggregates to absorb water by capillarity [37], field water capacity $\left(F_{W}, \%\right)$ that is defined as water in the soil retained against gravity [38], and bulk density $\left(D, \mathrm{~g} / \mathrm{cm}^{3}\right)$ were calculated according to Equations (1), (2), (3), (4) and (5), respectively.

The total porosity $\left(P_{t}, \%\right)$, capillary porosity $\left(P_{c}, \%\right)$ and noncapillary porosity $\left(P_{n}, \%\right)$ of the soil were calculated according to Equations (6)-(8), respectively. The equations used [37,38] are given below.

$$
\begin{aligned}
S(\%) & =\frac{m_{0}-m_{4}}{m_{4}-m} \times 100 \\
S_{w}(\%) & =\frac{m_{1}-m_{4}}{m_{4}-m} \times 100 \\
C_{w}(\%) & =\frac{m_{2}-m_{4}}{m_{4}-m} \times 100 \\
F_{w}(\%) & =\frac{m_{3}-m_{4}}{m_{4}-m} \times 100 \\
D & =\frac{m_{4}-m}{v} \\
P_{t}(\%) & =\left(1-\frac{D}{D_{s}}\right) \times 100 \\
P_{c}(\%) & =C_{w} \times \frac{D}{V} \times 100 \\
P_{n}(\%) & =P_{t}(\%)-P_{c}(\%)
\end{aligned}
$$

where $m$ is the weight of the steel ring knife, $V$ is the volume of the soil core $\left(100 \mathrm{~cm}^{3}\right)$ and $D_{s}$ is the soil particle density, which is thought to be $2.65 \mathrm{~g} / \mathrm{cm}^{3}$ for Ultisols in China $[39,40]$.

After carefully removing the surface organic material and fine roots, the soil sample was air dried for $48 \mathrm{~h}$ at room temperature $\left(22^{\circ} \mathrm{C}\right)$ and ground to pass a 2-mm sieve for analyses of chemical properties and enzyme activity. 
For soil $\mathrm{pH}$, available $\mathrm{N}$, available $\mathrm{P}$, and exchangeable $\mathrm{K}$ analyses, the air-dried soil was passed through a 2-mm mesh sieve. For organic carbon and total $\mathrm{P}$ and total $\mathrm{K}$ measurement, the air-dried soil was then further sieved to $0.15 \mathrm{~mm}$. For total $\mathrm{N}$ analysis, the air-dried soil was passed through a $0.25-\mathrm{mm}$ mesh sieve [41]. The soil $\mathrm{pH}$ was measured in deionized water $(1: 2.5 \mathrm{w} / \mathrm{w})$ at $20{ }^{\circ} \mathrm{C}$. The soil organic carbon (SOC) was analyzed using rapid dichromate oxidation of organic carbon. The soil total $\mathrm{N}$ was estimated by Kjeldahl digestion [42]. Total $\mathrm{P}$ was determined by molybdenum blue colorimetry and total $\mathrm{K}$ by atomic absorption spectroscopy following $\mathrm{NaOH}$ digestion [41]. The available $\mathrm{N}$ was released and transformed to $\mathrm{NH}_{3}$ by reaction with $1.07 \mathrm{M} \mathrm{NaOH}$ and $\mathrm{FeSO}_{4}$ powder at $40{ }^{\circ} \mathrm{C}$ for 24 hours, and then absorbed with $2 \%$ (w/v) $\mathrm{H}_{3} \mathrm{BO}_{3}$ and titrated with $0.005 \mathrm{M} \mathrm{H}_{2} \mathrm{SO}_{4}$ [41]. The available $\mathrm{P}$ was extracted with a solution of Bray-1 $\left(0.03 \mathrm{M} \mathrm{NH}_{4} \mathrm{~F}-0.025 \mathrm{M} \mathrm{HCl}\right)$ and measured by colorimetry. Exchangeable $\mathrm{K}$ was extracted with $1.0 \mathrm{M} \mathrm{NH}_{4} \mathrm{OAc}(\mathrm{pH}=7.0)$ and then determined by atomic absorption spectroscopy [41].

Urease activity was determined using urea $(10 \% \mathrm{w} / \mathrm{v})$ as the substrate, and incubating the soil sample for 24 hours at $37{ }^{\circ} \mathrm{C}$ and measuring the $\mathrm{NH}_{3}$ released colorimetrically. To determine the acid phosphatase activity, $5 \mathrm{~g}$ of soil and $20 \mathrm{~mL} 0.5 \%$ disodium phenyl phosphate were added to a $50-\mathrm{mL}$ flask, and then incubated for 2 hours at $37^{\circ} \mathrm{C}$. Five milliliters of filtrate was added to a $50-\mathrm{mL}$ flask and the concentration of $p$-nitrophenol was measured by absorbance. To determine catalase activity, $2 \mathrm{~g}$ of soil, $40 \mathrm{~mL}$ deionized water, and $5 \mathrm{~mL} 0.3 \% \mathrm{H}_{2} \mathrm{O}_{2}$ were added to a $100-\mathrm{mL}$ flask, and then vibrated for $30 \mathrm{~min}$, after which $5 \mathrm{~mL}$ of $3 \mathrm{~N} \mathrm{H}_{2} \mathrm{SO}_{4}$ was added. The solution was filtered, and $25 \mathrm{~mL}$ of filtrate was titrated against $0.1 \mathrm{~N} \mathrm{KMnO}_{4}$ [43].

\subsection{Statistical Analyses}

Results are expressed on the basis of the oven-dry $\left(105^{\circ} \mathrm{C}, 48\right.$ hours $)$ weight of the material. Means $(n=24)$ and standard errors of the means were calculated for soil bulk density, organic carbon, and so on. The data were found to be normally distributed with the Kolmogorov-Smirnov test. Changes in different variables over time after the wildfire were analyzed using a two-way ANOVA and Tukey's test. Differences were considered significant at the $P<0.05$ level. All tests were carried out using SAS Version 8.2 (SAS Institute, Cary, NC, USA).

\section{Results}

The wildfire effects in soil physical properties were significantly different between treatment variation, time variation, and treatment-by-time interaction in the two-way ANOVA $(p \leq 0.070)$ (Table 1). Wildfire-induced changes in soil chemical properties $(p \leq 0.0289)$ and enzyme activities $(p \leq 0.0007)$ were similar to soil physical properties. Wildfire significantly altered soil bulk density, which significantly increased and then significantly decreased with increasing post-fire time (Figure 1). Relative to the unburned soil, bulk density increased in the burned soil one and four years post-fire by $30 \%$ and $20 \%$, respectively, and then returned to the level in the unburned soil seven years post-fire. There was no significant effect of time after burning on soil capillary porosity, reflecting only a slight change in this parameter from 2006 to 2013. Soil non-capillary porosity significantly decreased by $17 \%, 38 \%$, and $32 \%$ in the soils 0 , one and four years post-fire, respectively, relative to the unburned soil, and then returned to levels of the unburned soil by 2013 . Soil capillary moisture decreased by $9 \%$, 
$23 \%, 2 \%$, and $11 \%$ in the soils 0 , one, four, and seven years post-fire, respectively, compared with the unburned soil and the significant decrease in soil capillary moisture was only detected one year after the fire.

Soil pH increased significantly from 4.6 (2006, pre-burn condition) up to 5.6 in the soil one-year post-fire and then decreased progressively to 4.7 and 4.5 in the soils four and seven years post-fire, respectively, whereas it decreased from 4.6 to 4.4 in the unburned soils (Figure 2). The SOC significantly increased by $35 \%$ and $29 \%$ in the soils 0 and one year post-fire, respectively, and then significantly decreased by $53 \%$ and $57 \%$ in the soils four and seven years post-fire, respectively, relative to the unburned soil.

Table 1. Two-way ANOVA results for all measured variables in forest soil.

\begin{tabular}{ccccccc}
\hline Variable & \multicolumn{2}{c}{ Treatment effect } & \multicolumn{2}{c}{ Time effect } & \multicolumn{2}{c}{ Treatment $\times$ time } \\
\cline { 2 - 7 } & $\boldsymbol{F}$-value & $\boldsymbol{p}$-value & $\boldsymbol{F}$-value & $\boldsymbol{p}$-value & $\boldsymbol{F}$-value & $\boldsymbol{p}$-value \\
\hline Bulk density & 82.06 & $<0.0001$ & 14.75 & $<0.0001$ & 29.14 & $<0.0001$ \\
Capillary porosity & 15.59 & 0.0012 & 5.8 & 0.0070 & 6.21 & 0.0053 \\
Noncapillary porosity & 44.94 & $<0.0001$ & 7.58 & 0.0020 & 7.06 & 0.0031 \\
Capillary moisture & 141.35 & $<0.0001$ & 28.91 & $<0.0001$ & 23.32 & $<0.0001$ \\
pH & 77.96 & $<0.0001$ & 44.56 & $<0.0001$ & 37.68 & $<0.0001$ \\
Organic carbon & 122.74 & $<0.0001$ & 125.20 & $<0.0001$ & 395.35 & $<0.0001$ \\
Total N & 11053.0 & $<0.0001$ & 31.82 & $<0.0001$ & 54.31 & $<0.0001$ \\
Available N & 50.46 & $<0.0001$ & 1127.31 & $<0.0001$ & 1145.71 & $<0.0001$ \\
Total P & 27.65 & $<0.0001$ & 3.90 & 0.0289 & 25.71 & $<0.0001$ \\
Available P & 272.44 & $<0.0001$ & 521.10 & $<0.0001$ & 558.74 & $<0.0001$ \\
Total K & 809.47 & $<0.0001$ & 224.74 & $<0.0001$ & 224.04 & $<0.0001$ \\
Available K & 51.14 & $<0.0001$ & 1381.81 & $<0.0001$ & 1442.90 & $<0.0001$ \\
Urease & 26513.6 & $<0.0001$ & 667.09 & $<0.0001$ & 9.63 & 0.0007 \\
Acid phosphatase & 20344.6 & $<0.0001$ & 182.03 & $<0.0001$ & 257.04 & $<0.0001$ \\
Catalase & 2264.07 & $<0.0001$ & 361.95 & $<0.0001$ & 77.03 & $<0.0001$ \\
\hline
\end{tabular}

Total $\mathrm{N}$ concentrations increased in the soils 0 and one year post-fire relative to the unburned soil, and then decreased progressively in the soils four and seven years post-fire. Total $\mathrm{N}$ was significantly correlated with SOC $(p=0.0360)$ and available $\mathrm{N}(p=0.0001)$, so available $\mathrm{N}$ followed a similar pattern as SOC and total $\mathrm{N}$, showing a significantly higher concentration in the soils 0 and one year post-fire relative to the unburned soil. However, this flush of available $\mathrm{N}$ was short lived, and the concentration significantly decreased to a value lower than that in the unburned soil four and seven years after the wildfire. 
Figure 1. Soil physical properties along a wildfire-induced time span; A, bulk density; $\mathbf{B}$, capillary porosity; $\mathbf{C}$, non-capillary porosity; $\mathbf{D}$, capillary water; each point represents $N=24$ with the standard error of the mean indicated; o, burned soil; $\Delta$, unburned soil; standard errors are shown by vertical bars.
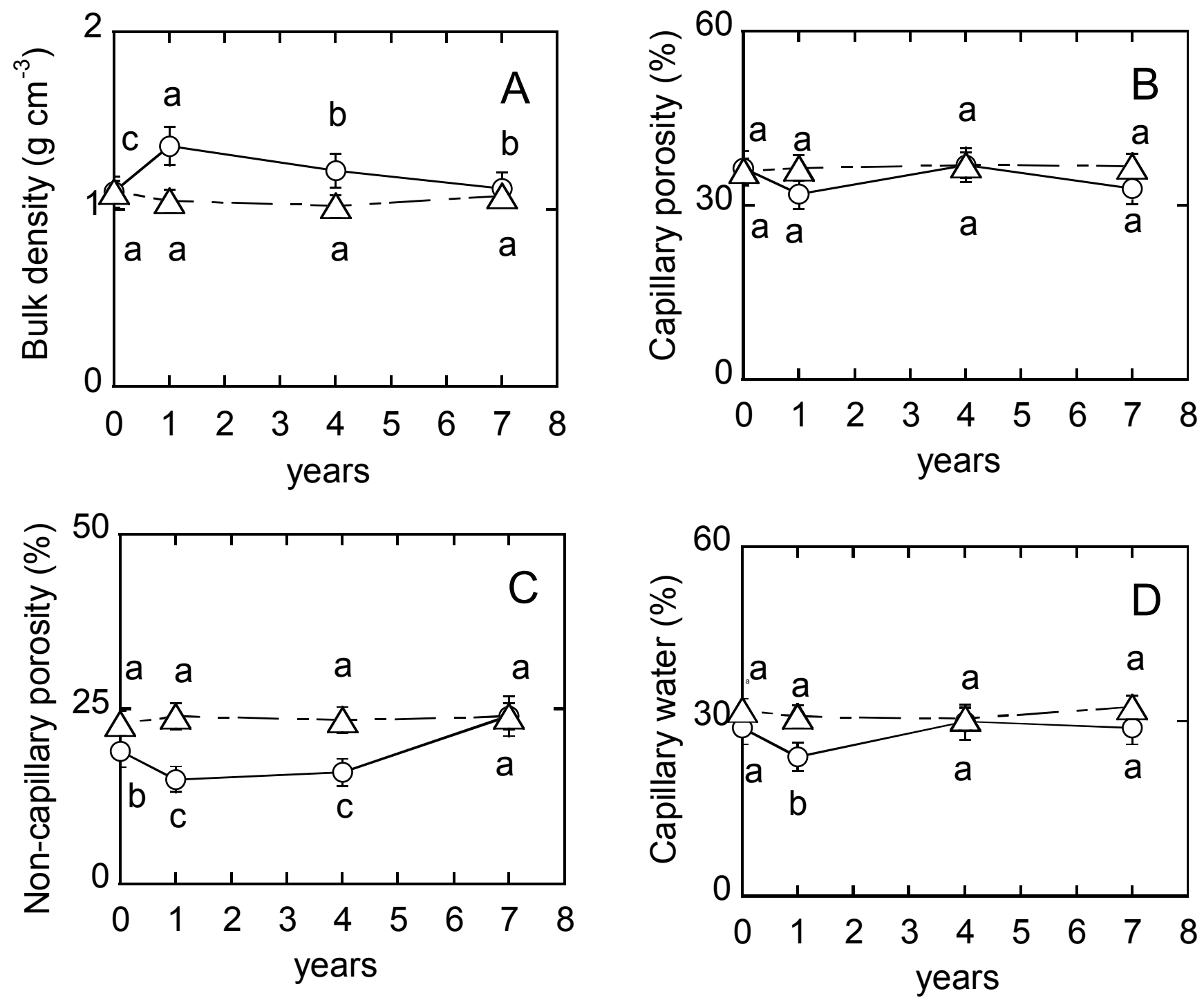

Total P concentration significantly increased immediately after the wildfire. There was no significant difference in total $\mathrm{P}$ between the soil one-year post-fire and the unburned soil. However, four years after the wildfire, total $\mathrm{P}$ became significantly lower in the burned soils and then remained at this level. Available $\mathrm{P}$ showed a higher concentration 0 and one year after the wildfire than in the unburned soil, and then decreased progressively in the soils four and seven years post-fire.

Wildfire slightly increased the total K concentration immediately after the wildfire, which decreased slightly in the soil one-year post-fire, and continued to decrease in the soils four and seven years post-fire. Exchangeable K significantly increased immediately after the wildfire and decreased in the soil one and four years post-fire relative to the unburned soil. Seven years post-fire this parameter remained at the level of the four years post-fire soil. 
Figure 2. Soil chemical properties along a wildfire-induced time span; $\mathbf{A}$, soil $\mathrm{pH} ; \mathbf{B}$, soil organic carbon; $\mathbf{C}$, total $\mathrm{N} ; \mathbf{D}$, available $\mathrm{N} ; \mathbf{E}$, total $\mathrm{P} ; \mathbf{F}$, available $\mathrm{P} ; \mathbf{G}$, total $\mathrm{K}$; $\mathbf{H}$, exchangeable $\mathrm{K}$; each point represents $N=24$ with the standard error of the mean indicated; $\circ$, burned soil; $\Delta$, unburned soil; standard errors are shown by vertical bars.
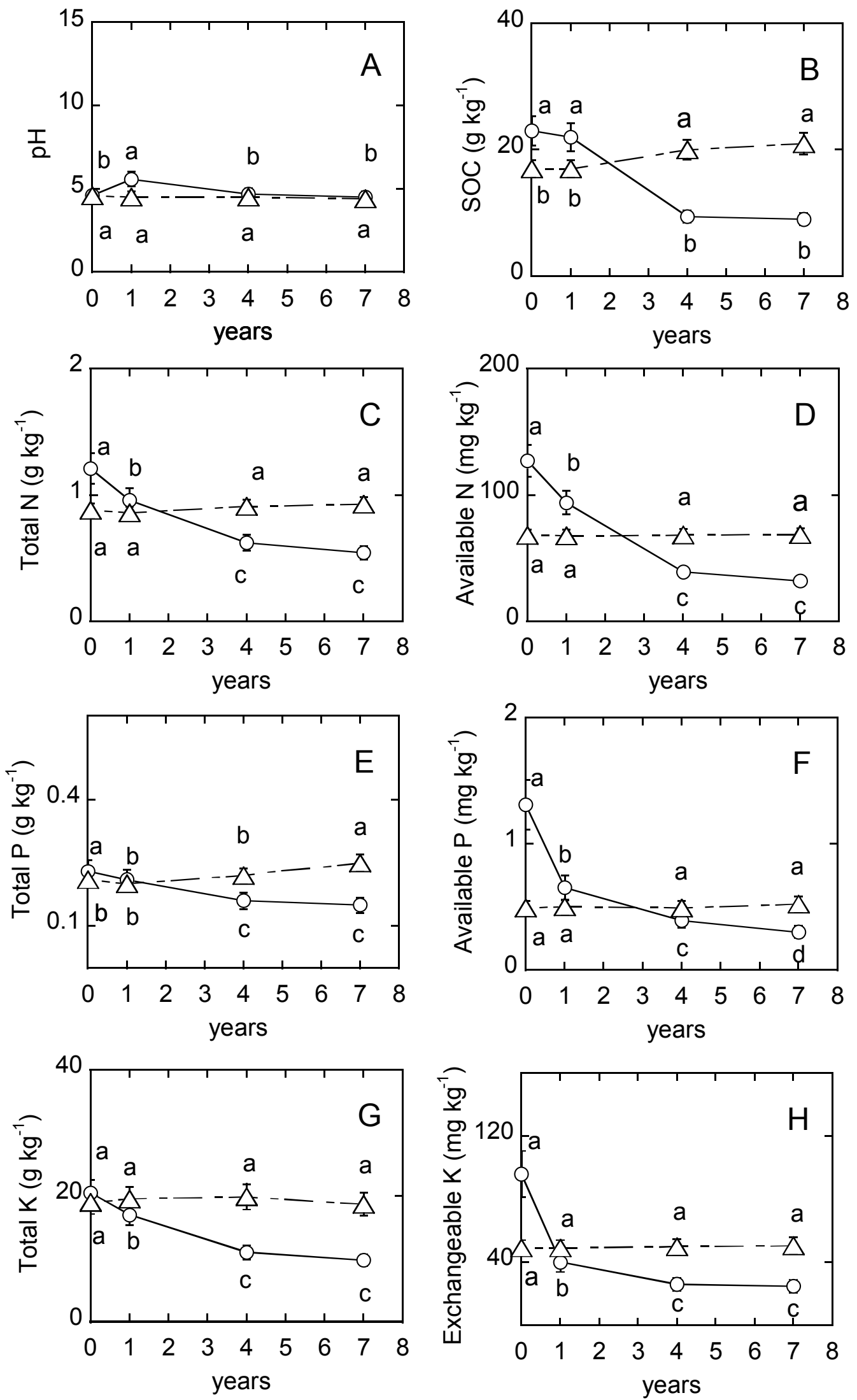
Compared with the unburned soil, enzyme activity after the wildfire significantly decreased, and the decrease ranged from $53 \%$ to $65 \%, 59 \%$ to $66 \%$ and $25 \%$ to $69 \%$ for urease activity, acid phosphatase activity, and catalase activity, respectively (Figure 3 ).

Figure 3. Soil enzyme activity along a wildfire induced time span; A, urease activity; B, acid phosphatase activity; C, catalase activity; each point represents $N=24$ with the standard error of the mean indicated; $\circ$, burned soil; $\Delta$, unburned soil; standard errors are shown by vertical bars.
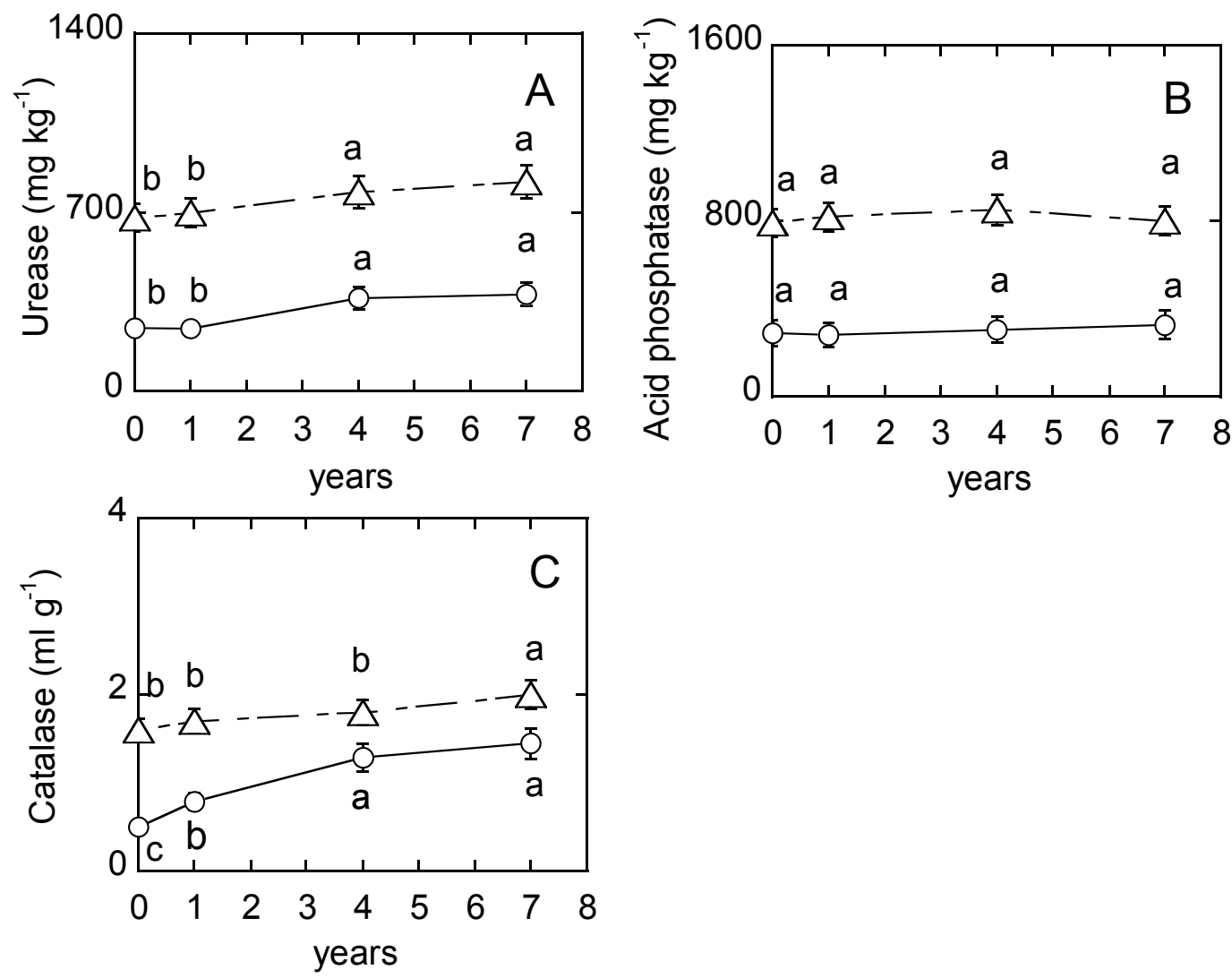

\section{Discussion}

\subsection{Soil Physical Properties}

Most studies of wildfire focus on soil organic and chemical characteristics, with few reporting their effect on soil bulk density, soil porosity, and capillary moisture capacity, which can be profoundly affected by fires $[44,45]$. Organic matter and clay are crucial to the formation of structure in the surface soil, which provides the macropore spaces needed for water movement and storage $[6,46]$. Wildfires can destroy stable organic matter-clay linkages and change clay mineralogy to relatively inert clays by burning litter and organic matter [47]. Wildfires also burn vegetation. Vegetation and the litter layer can mitigate the impact of raindrops on soil and break up runoff [48]. In the present study, the wildfire significantly increased bulk density relative to the unburned soil, which may be a result of the collapse of organic-mineral aggregates [49] and sealing because of clogging of soil pores by the ash or the freed clay minerals $[7,50]$. 
Organic matter and soil structure affect soil porosity [6] and were profoundly affected by the wildfire in the present study, resulting in a significant decrease in macropores (non-capillary porosity). When fire consumes vegetation and underlying litter layers that mitigate the impact of rainfall on the soil, bare soil surfaces can seal off under the impact of raindrops, resulting in much higher rates of surface runoff, which contributes to decreased water-holding capacity of a soil [7,51]. This is the probable explanation for the significant decrease in the soil capillary moisture after the wildfire.

\subsection{Soil pH}

Soil $\mathrm{pH}$ increased significantly one year after the wildfire and then returned to the level of the unburned soil. This behavior supports observations by several authors, who have reported an increase in soil $\mathrm{pH}$ following forest burning and for the effect to last for one to several years [29,52]. Arocena and Opio [10] also reported that soil $\mathrm{pH}$ increased by 2 or $3 \mathrm{pH}$ units for two or three years after fires, and Rhoades et al. [53] found that soil $\mathrm{pH}$ was higher in logged burnout areas for more than three years after combustion of downed logs compared with adjacent soil. Úbeda et al. [54] observed that pH returned to pre-fire values just one year after the fire. This increase is generally due to the combustion of organic matter and ash production. Burns are presumed to cause losses of un-dissociated organic acids in the litter and soil by combustion, removing them from the system [10]. In addition, the leaching of alkaline metals from the ash into the soil complex and the associated consumption of hydrogen ions in the formation of water could result in an increase in $\mathrm{pH}$ after fires [17,52]. The $\mathrm{pH}$ increase from the one-year post-burn soil may be related to losses of organic acids by heating [10]. In the present study, the increase in $\mathrm{pH}$ from the burned soil is an ephemeral phenomenon with a recovery time of one year. This is in agreement with rapid removal of ashes by wind or rainfall reported by Jordán et al. [55] and Pereira et al. [56].

\subsection{Soil Organic Carbon}

Fire affects carbon cycling in forest soils directly by oxidizing many of the available compounds, and indirectly by changing environmental constraints on microbial activity [17]. The SOC content increased in the 0- and one-year post-fire soil, which is consistent with Zhang et al. [57], who observed that a wildfire contributed to an increase of organic substances in soils under a $P$. massoniana forest. Johnson and Curtis [58] reported a significant $8 \%$ increase in soil carbon in burned A horizon after a meta-analysis across 48 studies. This increase may be a result of biochemically protected unburned residues being incorporated into the mineral soil and an increase in recalcitrant SOM, which slows SOM decomposition [12]. SOC decreased in the soils four and seven years post-fire, which may be explained by soil erosion following heavy rainfalls. Fires increase erosion rates by removing the vegetation cover and litter as well as altering the soil surface conditions [59]. Heavy rainfalls between April and June during the four years post-fire might have been a key factor contributing to the decreased SOC content, which may erode the soil surface and remove organic matter-rich fine sediments from the soil surface [52]. 


\subsection{Soil Nutrients}

Despite the dramatic loss of forest floor $\mathrm{N}$, the soil total $\mathrm{N}$ content showed an increase and a significantly progressive decrease after the wildfire. The influence of fire on soil total $\mathrm{N}$ pools has been inconsistent with reports of increases [60-62], decreases [63,64], and no change $[65,66]$. This inconsistency may be caused by environmental factors, such as soil moisture, leaching, soil erosion, and the soil depth sampled influencing soil $\mathrm{N}$ [17]. Therefore, it appears that more studies are needed to understand $\mathrm{N}$ changes after vegetation fires. Because of its low volatilization temperature, most $\mathrm{N}$ in litter and soil surface layers that burn is lost to the atmosphere and can have large impacts on the long-term $\mathrm{N}$ budgets of forest ecosystems [36]. Moderate-intensity fires can cause large losses of $\mathrm{N}$ directly through consumption or $\mathrm{NH}_{4}$ volatilization and $\mathrm{NO}_{3}$ leaching or overland flow [6]. Therefore, the wildfires lead to a decrease in total $\mathrm{N}$ in the long term. Nutrient loss is likely after fires, until vegetation is re-established, root activity is restored, and evapotranspiration returns to normal levels. Fire severity and vegetation type are also important factors affecting total $N$ change. Sands [67] demonstrated that burning a nutrient-poor sandy podzol resulted in large reductions in total $\mathrm{N}$ that were detectable 24 years after the fire [49].

Total $\mathrm{N}$ and available $\mathrm{N}$ followed a similar pattern as SOC, because nearly all soil $\mathrm{N}$ is contained in organic matter [68] and available $\mathrm{N}$ has been found to be highly correlated with the soil's total $\mathrm{N}$ content $[69,70]$. The available $\mathrm{N}$ significantly increased in burned soil within one year after the fire. The response of available $\mathrm{N}$ to the wildfire supports many other studies, showing an initial increase [66,71]. Moderate- to high-intensity fires convert most soil organic $\mathrm{N}$ to inorganic forms [7]. Therefore, soil inorganic $\mathrm{N}$ generally increases with fire $[12,72]$ due to heat-induced $\mathrm{NH}_{4}{ }^{+}$release from clay complexes (during fire), deposition of organic $\mathrm{N}$ in ash, and enhanced ammonification rates [73,74]. Weston and Attiwill [75] quantified the fire-induced inorganic $\mathrm{N}$ increase as being three times the original concentration over the first 205 days, followed by a return to the pre-fire level after 485 days.

The available $\mathrm{N}$ in burned soil four and seven years post-fire significantly decreased to a level lower than in the unburned soil, which is similar to previous results. Miesel et al. [76] reported a significant increase in mineral soil inorganic $\mathrm{N}$ concentrations. However, any increase in available $\mathrm{N}$ is often relatively short lived [66] and can last several months to several years, depending on the vegetative recovery and the regional climate [17]. If the high levels of available $\mathrm{N}$ after fire are not promptly taken up by plants, this $\mathrm{N}$ in burned topsoils and surface ash is susceptible to leaching losses, and erosion by runoff [77] and wind [49,78]. Therefore, heavy rainfalls occurring between April and June and steep slopes in the study area may contribute to a decrease in post-fire available $\mathrm{N}$.

The increase in soil total $\mathrm{P}$ was significant immediately after the wildfire and small in the soils one-year post-fire and significantly decreased from four years after the wildfire. The main pool for P is in the soil $(94 \%-98 \%)$ and not in the litter. Therefore, severe burning of vegetation and litter has a small impact on $\mathrm{P}$ pools compared with $\mathrm{N}$ pools. However, organic forms of $\mathrm{P}$ in the litter are made more readily available to plants following fire [6]. Losses of $P$ through burning may be more serious for ultisols with low $\mathrm{P}$, because natural replacement of $\mathrm{P}$ from rainfall or mineral weathering is very low in subtropical forests in South China, and even small absolute losses of $\mathrm{P}$ would require a long fire-free period to be replenished. For example, Klopatek [79] determined that P concentrations beneath pinyon-juniper canopies, 35 years after a wildfire, had not recovered to levels found in stands that had 
not burned in 300 years. Erosion can effectively remove nutrients from a burned soil because nutrient contents in ash far exceed concentrations in soils and litter, and ash is readily removed by runoff. Loss of vegetation cover and increased soil water repellency after fires contribute to increased runoff and surface erosion after fires [51]. Post-fire weather can also influence soil nutrient contents. Heavy rainfalls immediately after a burn can lead to a loss of the nutrient-rich ash layer through erosion and overland flow [80]. At the study site heavy rainfall occurred shortly (one month) after the wildfire, potentially contributing to greater $\mathrm{P}$ losses. The $\mathrm{P}$ concentration is typically low in ultisols of subtropical forests in South China and is predominantly cycled through organic pools in the upper soil layers, which often limits tree growth. If this is the case, wildfires in $P$. massoniana forests may result in smaller organic $\mathrm{P}$ pools and significant phosphorus leaching losses.

The wildfire resulted in an enrichment of available $\mathrm{P}$ immediately and one year after the wildfire, which supports Certini [7]. Burning converts soil $\mathrm{P}$ to orthophosphate [12,81] and has a positive effect on available $\mathrm{P}$ by inducing a change in soil $\mathrm{pH}$ toward neutrality. Therefore, fires result in an enrichment of available P [82]. Romanya et al. [83] found that the soil available P content was higher than pre-fire levels in a Eucalyptus forest seven months after slash burning. However, $\mathrm{P}$ enrichment after fire is typically short lived, and in this study had declined in the burned soil four years after the wildfire. The amounts of $\mathrm{P}$ that would have been released by ash could easily have been incorporated into the soil without detection, as orthophosphate binds to $\mathrm{Al}, \mathrm{Fe}$, and $\mathrm{Mn}$ oxides through chemisorption in acid soils of the study site. Available P can be lost by particulate transport of ash after a fire, or lost to runoff and erosion [36]. Macadam [84] found that nine months after slash burning, available P in the upper $30 \mathrm{~cm}$ of the mineral soil of a Picea-dominated forest had increased by up to $50 \%$ and began to diminish 21 months after the fire event. Therefore, the increased available $\mathrm{P}$ at the soil surface after fires will lead to decreased nutrient availability in the long term.

Concentrations of total and exchangeable $\mathrm{K}$ increased immediately after the wildfire and then continuously decreased in the soil. Fire-induced changes to soil nutrients other than $\mathrm{N}$ and $\mathrm{P}$ generally are slighter and more ephemeral and soil exchangeable capacity is decreased by fires [85] beyond the fire-associated nutrient enrichment period [7]. Adams and Boyle [86] reported that a month after a wildfire, available $\mathrm{K}$ in the soil of a Quercus rubra-Populus grandidentata forest was significantly higher than pre-fire levels, but the increases were almost gone after a further three months. Tomkins et al. [87] found soil $\mathrm{K}$ to increase for six months following fire in a Eucalyptus forest. Heavy rainfall one month after the wildfire in the study area may have led to the observed decrease in exchangeable $\mathrm{K}$ because of the loss of a high-density-charged fraction such as organic matter, which can lead to K being lost by particulate transport of ash, runoff, or erosion [36].

The magnitude of wildfire effect on soil chemical properties may be largely driven by climate and time length following wildfires. Zhang et al. [57] found that SOM, total N, P and K and available N, P, and $\mathrm{K}$ significantly increased two to four months following a wildfire in an artificial $P$. massoniana forest in Guizhou Province, southwest China. Liu et al. [88] observed that SOM, and total N significantly increased, total $\mathrm{P}$ remained steady, whereas total $\mathrm{K}$ and available $\mathrm{N}$, $\mathrm{P}$, and $\mathrm{K}$ significantly decreased from one to five years following wildfires in a P. massoniana forest in Hunan Province, south China. Kong et al. [89] showed significant decreases in SOM and total $\mathrm{N}$ and significant increases in available $\mathrm{N}$, $\mathrm{P}$, and $\mathrm{K}$ one year after a wildfire in a Larix gmelini forest in Great Xing'an Mountains, Northeast China, whereas persistent decreases in SOM, total N, P, and K have been reported twenty years following 
wildfires in Great Xing'an Mountains [90]. In accordance with results of $\mathrm{Gu}$ et al. [90], our study demonstrated significant decreases in SOM and N, P, and $\mathrm{K}$ after a wildfire. A higher rainfall occurred at our study site compared to the study site of Liu et al. [88] (2142 $\mathrm{mm}$ vs. $1410 \mathrm{~mm}$ ), which may be responsible for the disagreement in dynamics of SOM and total $\mathrm{N}$ between our study site and the site of Liu et al., because wildfire-caused increases in soil nutrients may lose due to strong leaching [9].

\subsection{Soil Enzymes}

Analyzing a suite of microbial enzymes along a time continuum that are active under variable environmental conditions can provide an estimate of fire effects on microbial activity and a glimpse into the below-ground functional changes that accompany fire [17]. Urease is an enzyme that catalyzes the hydrolysis of urea into carbon dioxide and ammonia, and affects $\mathrm{N}$ release from SOM. Phosphatase activity is involved in $\mathrm{P}$ cycling in soils and is regulated by the soil microclimate and organic carbon and phosphorus availability [17]. Catalase catalyzes the decomposition of hydrogen peroxide, a powerful and potentially harmful oxidizing agent, to water and oxygen. It is a very important enzyme in protecting cells from oxidative damage.

Urease, phosphatase, and catalase activities were significantly lower in the burned soil than in the unburned soil during the experimental period. This result supports several studies that have reported reduced urease activity [91] and acid phosphatase activity in forest soils after fire [19,76]. These decreases may be the result of decreased microbial biomass and/or activity, as Nannipieri et al. [92] and Kandeler and Eder [93] have shown strong correlations between changes in microbial biomass and acid phosphatase activity. Elevated available soil $\mathrm{P}$ may reduce acid phosphatase activity by reducing the need for microbial expenditure of the enzyme [17]. Soil enzyme activity is limited by substrate chemistry and availability [94]. Deteriorating environmental conditions or substrate chemistry could therefore significantly decrease enzyme activity. Following a moderate- to high-intensity fire, microbes can be killed directly through burning or be affected by oxidizing organic $\mathrm{C}$ of the soil surface as well as completely removing the vegetation, thus, reducing potential OM inputs to soil and the nutrient content, which may affect soil enzyme activity. The changes in soil enzyme activity are consistent with the time post-fire. The fact that soil enzyme activity had not returned to pre-fire levels within seven years suggests that overall microbial activity, organic matter, and nutrients were still lower than in unburned sites.

\section{Conclusions}

In summary, we found evidence that the wildfire has a significant impact on soil physical, chemical, and biological properties in the P. massoniana forest. The significant differences in soil bulk occurred one and four years after the wildfire and significant decrease in macrospores were found seven years following the wildfire. Soil organic carbon, total $\mathrm{N}$ and $\mathrm{P}$, and available $\mathrm{N}$ and $\mathrm{P}$, total $\mathrm{K}$ and exchangeable $\mathrm{K}$ significantly decreased in the burned soil compared with the unburned soil, and they also significantly decreased along the burned time-span. Urease, acid phosphatase, and catalase activities significantly decreased as a result of the fire. In addition, urease and catalase activities also significantly increased after the fire. Our results indicated that even moderate-severity wildfires would lead to long-term changes in physical, chemical, and biochemical properties of soil in P. massoniana ecosystems, probably as a joint effect of burning, climate, and topography. In view of climate change, 
more extreme droughts may occur that will lead to more frequent forest wildfires [95]. The $P$. massoniana forest represents some of moderate-severity forest fire plots in China, so long-term studies of wildfire effects on a range of forest soils are critical for understanding effects of these wildfires.

\section{Acknowledgments}

The study was partially supported by the Foundation of Guangdong Forestry Bureau (No. 4400-F11031, No. 4400-F11055).

\section{Author Contributions}

Li Xue conceived the ideas and led the writing; Qiujing Li analyzed the data, and Hongyue Chen conducted the field investigation.

\section{Conflicts of Interest}

The authors declare no conflict of interest. The findings and conclusions in this article are those of the authors and do not necessarily represent the views of their respective organizations.

\section{References}

1. Gray, D.M.; Dighton, J. Nutrient utilization by pine seedlings and soil microbes in oligotrophic pine barrens forest soils subjected to prescribed fire treatment. Soil Biol. Biochem. 2009, 41, 1957-1965.

2. Dezzeo, N.; Chacón, N. Carbon and nutrients loss in aboveground biomass along a fire induced forest-savanna gradient in the Gran Sabana, southern Venezuela. For. Ecol. Manag. 2005, 209, $343-352$.

3. Viegas, D.X. Forest fires in Portugal in 2005-an overview. Int. For. Fire News 2006, 34, 22-30.

4. Castro, A.C.M.; Carvalho, J.P.; Meixedo, J.P. A qualitative description of soil parameters variation due to a prescribed fire in Portuguese northwestern forests using Fuzzy Boolean Nets-The case study of Cabreira mountain. Geoderma 2012, 191, 89-96.

5. Neill, C.; Patterson, W.A., III; Crary, D.W., Jr. Responses of soil carbon, nitrogen and cations to the frequency and seasonality of prescribed burning in a Cape Cod oak-pine forest. For. Ecol. Manag. 2007, 250, 234-243.

6. Neary, D.G.; Klopatek, C.C.; DeBano, L.F.; Ffolliott, P.F. Fire effects on belowground sustainability: A review and synthesis. For. Ecol. Manag. 1999, 122, 51-71.

7. Certini, G. Effects of fire on properties of forest soils: A review. Oecologia 2005, 143, 1-10.

8. DeBano, L.F.; Neary, D.G.; Ffolliott, D.F. Fire's Effects on Ecosystems; John Wiley and Sons, Inc.: New York, NY, USA, 1998; p. 612.

9. Michalzik, B.; Martin, S. Effects of experimental duff fires on C, N and P fluxes into the mineral soil at a coniferous and broadleaf forest site. Geoderma 2013, 197-198, 169-176.

10. Arocena, J.M.; Opio, C. Prescribed fire-induced changes in properties of subboreal forest soils. Geoderma 2003, 113, 1-16. 
11. Wells, C.G.; Campbell, R.E.; DeBano, L.F.; Lewis, C.E.; Fedriksen, R.L.; Franklin, E.C.; Froelich, R.C.; Dunn, P.H. Effects of fire on soil: A state-of-knowledge review. In USDA Forest Service General Technical Report WO-7; USDA Forest Service: Washington, DC, USA, 1979.

12. Scharenbroch, B.C.; Nix, B.; Jacobs, K.A.; Bowles, M.L. Two decades of low-severity prescribed fire increases soil nutrient availability in a Midwestern, USA oak (Quercus) forest. Geoderma 2012, 183-184, 80-91.

13. Wanthongchai, K.; Bauhus, J.; Goldammer, J.G. Nutrient losses through prescribed burning of aboveground litter and understorey in dry dipterocarp forests of different fire history. Catena $\mathbf{2 0 0 8}$, 74, 321-332.

14. Ulery, A.L.; Graham, R.C. Forest fire effects soil color and texture. Soil Sci. Soc. Am. J. 1993, 57, 135-140.

15. Wüthrich, C.; Schaub, D.; Weber, M.; Marxer, P.; Conedera, M. Soil respiration and soil microbial biomass after fire in a sweet chestnut forest in southern Switzerland. Catena 2002, 48, 201-215.

16. Miesel, J.R.; Goebel, P.C.; Corace, R.G., III; Hix, D.M.; Kolka, R.; Palik, B.; Mladenoff, D. Fire Effects on soils in Lake States Forests: A compilation of published research to facilitate long-term investigations. Forests 2012, 3, 1034-1070.

17. Hamman, S.T.; Burke, I.C.; Knapp, E.E. Soil nutrients and microbial activity after early and late season prescribed burns in a Sierra Nevada mixed conifer forest. For. Ecol. Manag. 2008, 256, 367-374.

18. Bárcenas-Moreno, G.; García-Orenes, F.; Mataix-Solera, J.; Mataix-Beneyto, J.; Bååth, E. Soil microbial recolonisation after a fire in a Mediterranean forest. Biol. Fertil. Soils 2011, 47, 261-272.

19. Boerner, R.E.J.; Decker, K.L.M.; Sutherland, E.K. Prescribed burning effects on soil enzyme activity in a southern Ohio hardwood forest: A landscape-scale analysis. Soil Biol. Biochem. 2000, 32, 899-908.

20. Boerner, R.E.J.; Brinkman, J.A.; Smith, A. Seasonal variations in enzyme activity and organic carbon in soil of a burned and unburned hardwood forest. Soil Biol. Biochem. 2005, 37, 1419-1426.

21. Carter, M.C.; Foster, C.D. Prescribed burning and productivity in southern pine forests: A review. For. Ecol. Manag. 2004, 191, 93-109.

22. Geldenhuys, C.J.; van Wilgen, B.W. Fire effects on the maintenance of biodiversity, soil and nutrients. In Wildland Fire Management Handbook for Sub-Sahara Africa; Goldammer, J.G., de Ronde, C., Eds.; Global Fire Monitoring Center (GFMC): Freiburg, Germany, 2004; pp. 88-113.

23. Morley, S.; Grant, C.; Hobbs, R.; Cramer, V. Long-term impact of prescribed burning on the nutrient status and fuel loads of rehabilitated bauxite mines in Western Australia. For. Ecol. Manag. 2004, 190, 227-239.

24. Kashian, D.M.; Romme, W.H.; Tinker, D.B.; Turner, M.G.; Ryan, M.G. Carbon storage on landscapes with stand-replacing fires. Bioscience 2006, 56, 598-606.

25. Gough, C.M.; Vogel, C.S.; Harrold, K.H.; George, K.; Curtis, P.S. The legacy of harvest and fire on ecosystem carbon storage in a north temperate forest. Glob. Change Biol. 2007, 13, 1935-1949.

26. Irvine, J.; Law, B.E.; Hibbard, K.A. Postfire carbon pools and fluxes in semiarid ponderosa pine in Central Oregon. Glob. Change Biol. 2007, 13, 1748-1760. 
27. Kurz, W.A.; Stinson, G.; Rampley, G.J.; Dymond, C.C.; Neilson, E.T. Risk of natural disturbances makes future contribution of Canada's forests to the global carbon cycle highly uncertain. Proc. Natl. Acad. Sci. USA 2008, 105, 1551-1555.

28. Meigs, G.W.; Donato, D.C.; Campbell, J.L.; Martin, J.G.; Law, B.E. Forest Fire Impacts on Carbon Uptake, Storage, and Emission: The Role of Burn Severity in the Eastern Cascades, Oregon. Ecosystem 2009, s12, 1246-1267.

29. Ponder, F., Jr.; Tadros, M.; Loewenstein, E.F. Microbial properties and litter and soil nutrients after two prescribed fires in developing savannas in an upland Missouri Ozark Forest. For. Ecol. Manag. 2009, 257, 755-763.

30. Xue, L.; Hagihara, A. Growth analysis on the competition-density effect in Chinese fir (Cunninghamia lanceolata) and Masson pine (Pinus massoniana) stands. For. Ecol. Manag. 2001, 150, 331-337.

31. Xue, L.; Lie, G.W.; Lu, G.C.; Shao, Y.R. Allometric scaling among tree components in Pinus massoniana stands with different sites. Ecol. Res. 2013, 28, 327-333.

32. Fölster, H.; Dezzeo, N.; Priess, J.A. Soil-vegetation relationship in base-deficient premontane moist forest-savanna mosaics of the Venezuelan Guayana. Geoderma 2001, 104, 95-113.

33. Priess, J.A.; Fölster, H. Microbial properties and soil respiration in submontane forests of Venezuelan Guayana: Characteristics and response to fertilizer treatments. Soil Biol. Biochem. 2001, 33, 503-509.

34. Baird, M.; Zabowski, D.; Everett, R.L. Wildfire effects on carbon and nitrogen in inland coniferous forests. Plant Soil 1999, 209, 233-243.

35. Johnson, D.W.; Murphy, J.D.; Susfalk, R.B.; Caldwell, T.G.; Miller, W.W.; Walker, R.F.; Powers, R.F. The effects of wildfire, salvage logging, and post-fire $\mathrm{N}$ fixation on the nutrient budgets of a Sierran forest. For. Ecol. Manag. 2005, 220, 155-165.

36. Johnson, D.; Murphy, J.D.; Walker, R.F.; Glass, D.W.; Miller, W.W. Wildfire effects on forest carbon and nutrient budgets. Ecol. Eng. 2007, 31, 183-192.

37. Bartoli, F.; Boivin, A.; Schiavon, M. Water and herbicide transient flow transport in field dried topsoils during controlled infiltration I. Water capillary and gravity-driven transient flows: A preliminary examination. Geoderma 2006, 135, 269-283.

38. Yi, X.S.; Li, G.S.; Yin, Y.Y. Comparison of three methods to develop pedotransfer functions for the saturated water content and field water capacity in permafrost region. Cold Reg. Sci. Technol. 2013, $88,10-16$.

39. Zhang, W.R.; Yang, G.Y.; Tu, X.Y.; Zhang, P. Determination of forest soil water-physical properties. China Criterion of Forest Technique. 1999, No. LY/T 1215. (In Chinese)

40. Cheng, S.; Yang, G.; Yu, H.; Li, J.Y.; Zhang, L. Impacts of Wenchuan Earthquake-induced landslides on soil physical properties and tree growth. Ecol. Indic. 2012, 15, 263-270.

41. Lu, R.K. Analytical Methods of Soil and Agricultural Chemistry; China Agricultural Science and Technology Press: Beijing, China, 2000. (In Chinese)

42. Bremner, J.M.; Mulvaney, C.S. Nitrogen-total. In Methods of Soil Analysis, Part 2, 2nd ed.; Page, A.L., Miller, R.H., Keeney, R.R., Eds.; American Society of Agronomy: Madison, WI, USA, 1982; pp. 595-624. 
43. Guan, S.Y. Soil Enzyme and Its Research Methods; Chinese Agricultural Press: Beijing, China. 1986; pp. 295-323. (In Chinese)

44. Powers, R.F.; Alban, D.H.; Miller, R.E.; Tiarks, A.E.; Wells, C.G.; Avers, P.E.; Cline, R.G.; Fitzgerald, R.O.; Loftus, N.S. Sustaining site productivity in North American forests: Problems and prospects. In Sustained Productivity of Forest Soils, Proceedings of the 7th North American Forest Soils Conference, University of British Columbia, Vancouver, BC, Canada, July 1988; Gessel, S.A., Lacate, D.S., Weetman, G.F., Powers, R.F., Eds.; pp. 49-79.

45. Yildiz, O.; Esen, D.; Karaoz, O.M.; Sarginci, M.; Toprak, B.; Soysal, Y. Effects of different site preparation methods on soil carbon and nutrient removal from Eastern beech regeneration sites in Turkey's Black Sea region. Appl. Soil Ecol. 2010, 45, 49-55.

46. Neary, D.G.; Jokela, E.J.; Comerford, N.B.; Colbert, S.R.; Cooksey, T.E. Understanding competition for soil nutrients-the key to site productivity on southeastern Coastal Plain spodosols. In Sustained Productivity of Forest Soils, Proceedings of the 7th North American Forest Soils Conference, University of British Columbia, Forestry Publications, Faculty of Forestry, Vancouver, BC, Canada, 24-28 July 1988; Gessel, S.P., Lacate, D.S., Weetman, G.F., Powers, R.F., Eds.; pp. 432-450.

47. Ketterings, Q.M.; Bigham, J.M.; Laperche, V. Changes in soil mineralogy and texture caused by slash and burn fires in Sumatra, Indonesia. Soil. Sci. Soc. Am. J. 2000, 64, 1108-1117.

48. Marcos, E.; Tarrega, R.; Luis-Calabuig, E. Comparative analysis of runoff and sediment yield with a rainfall simulator after experimental fire. Arid Soil Res. Rehab. 2000, 14, 293-307.

49. Giovannini, G.; Lucchesi, S.; Giachetti, M. Effects of heating on some physical and chemical parameters related to soil aggregation and erodibility. Soil Sci. 1988, 146, 255-261.

50. Durgin, P.B.; Vogelsang, P.J. Dispersion of kaolinite by water extracts of Douglas-fir ash. Can. J. Soil Sci. 1984, 64, 439-443.

51. McIntosh, P.D.; Laffan, M.D.; Hewitt, A.E. The role of fire and nutrient loss in the genesis of the forest soils of Tasmania and southern New Zealand. For. Ecol. Manag. 2005, 220, 185-215.

52. Granged, A.J.P.; Jordán, A.; Zavala, L.M.; Muñoz-Rojas, M.; Mataix-Solera, J. Short-term effects of experimental fire for a soil under eucalyptus forest (SE Australia). Geoderma 2011, 167-168, 125-134.

53. Rhoades, C.C.; Meier, A.J.; Rebertus, A.J. Soil properties in fire-consumed log burnout openings in a Missouri oak savanna. For. Ecol. Manag. 2004, 192, 277-284.

54. Úbeda, X.; Lorca, M.; Outeiro, L.R.; Bernia, S.; Castellnou, M. The effects of prescribed fire on soil quality (Prades Mountains, North East Spain). Int. J. Wildland Fire 2005, 14, 379-384.

55. Jordán, A.; González, F.A.; Zavala, L.M. Re-establishment of soil water repellency after destruction by intense burning in a Mediterranean heathland (SW Spain). Hydrol. Process 2010, 24, 736-748.

56. Pereira, P.; Bodí, M.; Úbeda, X.; Cerdà, A.; Mataix-Solera, J.; Balfour, V.; Woods, S. Las cenizas en el ecosistema suelo. In Actualización en métodos y técnicas para el estudio de los suelos afectados por incendios forestales; Cerdà, A., Jordán, A., Eds.; Càtedra deDivulgació de la Ciència, Universitat de València: Valencia, Spain, 2010; pp. 349-402.

57. Zhang, X.; Zhu, J.; Cui, Y.C.; Huo, D.; Wang, L.L.; Wu, P.; Chen, J.; Pan, D.Q.; Yang, C.H. Influence of fire on a Pinus massoniana soil in a karst mountain area at the center of Guizhou Province, China. Acta Ecol. Sin. 2011, 31, 5809-5817. (In Chinese with English abstract) 
58. Johnson, D.L.; Curtis, P.S. Effects of forest management on soil $\mathrm{C}$ and $\mathrm{N}$ storage: Meta analysis. For. Ecol. Manag. 2001, 140, 227-238.

59. Doerr, S.H.; Shakesby, R.A.; Walsh, R.P.D. Soil water repellency: Its causes, characteristics and hydrogeomorphological significance. Earth Sci. Rev. 2000, 51, 33-65.

60. Kovacic, D.A.; Swift, D.M.; Ellis, J.E.; Hakonson, T.E. Immediate effects of prescribed burning on mineral soil nitrogen in ponderosa pine of New Mexico. Soil Sci. 1986, 141, 71-75.

61. Schoch, P.; Binkley, D. Prescribed burning increased nitrogen availability in a mature loblolly pine stand. For. Ecol. Manag. 1986, 14, 13-22.

62. Covington, W.W.; Sackett, S.S. Soil mineral nitrogen changes following prescribed burning in ponderosa pine. For. Ecol. Manag. 1992, 54, 175-191.

63. Raison, R.J.; Khanna, P.K.; Woods, P.V. Mechanisms of element transfer to the atmosphere during vegetation fires. Can. J. For. Res. 1985, 15, 132-140.

64. Bell, R.L.; Binkley, D. Soil nitrogen mineralization and immobilization in response to periodic prescribed fire in a loblolly pine plantation. Can. J. For. Res. 1989, 19, 816-820.

65. Knoepp, J.D.; Swank, W.T. Comparison of available soil nitrogen assays in control and burned forest sites. Soil. Sci. Soc. Am. J. 1995, 59, 1750-1754.

66. Moghaddas, E.E.Y.; Stephens, S.L. Thinning, burning, and thin-burn fuel treatment effects on soil properties in a Sierra Nevada mixed conifer forests. For. Ecol. Manag. 2007, 250, 156-166.

67. Sands, R. Physical changes to sandy soils planted to radiate pine. In Proceedings of the IUFRO Symposium on Forest Site and Continuous Productivity, Seattle, Washington, 22-28 August 1982; Ballard, R., Gessel, S.P., Eds.

68. Busse, M.D.; DeBano, L.F. Soil biology. In Wildland Fire in Ecosystems: Effects of Fire on Soil and Water; General Technical Report RMRS-GTR-42-vol. 4; Neary, D.G., Ryan, K.C., DeBano, L.F., Eds.; USDA Forest Service, Rocky Mountain Research Station: Ogden, UT, USA, 2005, pp. 73-91.

69. Zhang, Y.M.; Wu, N.; Zhou, G.Y.; Bao, W.K. Changes in enzyme activities of spruce (Picea balfouriana) forest soil as related to burning in the eastern Qinghai-Tibetan Plateau. Appl. Soil Ecol. 2005, 30, 215-225.

70. Zhang, X.Y.; Sui, Y.Y.; Zhang, X.D.; Meng, K.; Herbert, S.J. Spatial Variability of Nutrient Properties in Black Soil of Northeast China. Pedosphere 2007, 17, 19-29.

71. Gundale, M.J.; DeLuca, T.H.; Fiedler, C.E.; Ramsey, P.W.; Harrington, M.G.; Gannon, J.E. Restoration management in a Montana ponderosa pine forest: Effects on soil physical, chemical, and biological properties. For. Ecol. Manag. 2005, 213, 25-38.

72. Kaye, J.; Hart, S.C. Ecological restoration alters nitrogen transformations in a ponderosa pine-bunchgrass ecosystem. Ecol. Appl. 1998, 8, 1052-1060.

73. Grogan, P.; Bruns, T.D.; Chapin, F.S., III. Fire effects on ecosystem nitrogen cycling in a Californian bishop pine forest. Oecologia 2000, 122, 537-544.

74. MacKenzie, M.D.; DeLuca, T.H.; Sala, A. Forest structure and organic matter analysis along a fire chronosequence in the low elevation forests of western Montana. For. Ecol. Manag. 2004, 203, $331-343$. 
75. Weston, C.J.; Attiwill, P.M. Effects of fire and harvesting on nitrogen transformations and ionic mobility in soils of Eucalyptus regnans forests of south-eastern Australia. Oecologia 1990, 83, 20-26.

76. Miesel, J.R.; Skinner, C.M.; Boerner, R.E.J. Impact of Fire on Soil Resource Patterns in a Northern California Montane Ecosystem. In Proceedings of the 23rd Tall Timbers Fire Ecology Conference: Fire in Grassland and Shrubland Ecosystems, Tall Timbers Research Station, Tallahassee, FL, USA, 17-20 October 2005, Masters, R.E., Galley, K.E.M., Eds.; pp. 94-102.

77. Wallbrink, P.; Blake, W.; Doerr, S.; Shakesby, R.; Humphreys, G.; English, P. Using Tracer Based Sediment Budgets to Assess Redistribution of Soil and Organic Material after Severe Bush Fires; Walling, D.E., Horowitz, A.J., Eds.; Sediment Budgets, IAHS Publication: Wallingford, UK, 2005; pp. 223-230.

78. Giardina, C.P.; Sanford, R.L.; Døckersmith, I.C. Changes in soil phosphorus and nitrogen during slash and burn clearing of a dry tropical forest. Soil Sci. Soc. Am. J. 2000, 64, 399-405.

79. Klopatek, J.M. Nitrogen mineralization and nitrification in mineral soils of pinyon-juniper ecosystems. Soil Sci. Soc. Am. J. 1987, 51, 453-457.

80. Huffman, E.L.; MacDonald, L.H.; Stednick, J.D. Strength and persistence of fire-induced soil hydrophobicity under ponderosa and lodgepole pine, Colorado Front Range. Hydrol. Process 2001, 15, 2877-2892.

81. Cade-Menun, B.J.; Berch, S.M.; Preston, C.M.; Lavkulich, L.M. Phosphorus forms and related soil chemistry of Podzolic soils on northern Vancouver Island. II. The effects of clear-cutting and burning. Can. J. For. Res. 2000, 30, 1726-1741.

82. Serrasolsas, I.; Khanna, P.K. Changes in heated and autoclaved forest soils of S.E. Australia. II. Phosphorus and phosphatase activity. Biogeochemistry 1995, 29, 25-41.

83. Romanya, J.; Khanna, P.K.; Raison, R.J. Effects of slash burning on soil phosphorus fractions and sorption and desorption of phosphorus. For. Ecol. Manag. 1994, 65, 89-103.

84. Macadam, A.M. Effects of broadcast slash burning on fuels and soil chemical properties in the sub-boreal spruce zone of central British Columbia. Can. J. For. Res. 1987, 17, 1577-1584.

85. Badìa, D.; Martí, C. Plant ash and heat intensity effects on chemical and physical properties of two contrasting soils. Arid Land Res. Manag. 2003, 17, 23-41.

86. Adams, P.W.; Boyle, J.R. Effects of fire on soil nutrients in clearcut and whole-tree harvest sites in Central Michigan. Soil Sci. Soc. Am. J. 1980, 44, 847-850.

87. Tomkins, I.B.; Kellas, J.D.; Tolhurst, K.G.; Oswin, D.A. Effects of fire intensity on soil chemistry in a eucalypt (Eucalyptus sp.) forest. Aust. J. Soil Res. 1991, 29, 25-47.

88. Liu, F.L.; Zhang, S.Y.; Zeng, S.Q.; Wang, W. Effects of fire disturbance on soil chemical properties of Pinus Massoniana forest. Chin. J. Soil Sci. 2009, 40, 1270-1275. (In Chinese with English abstract)

89. Kong, J.J.; Yang, J. Effects of fire on soil properties and nutrient availability in a Dahurian larch forest in Great Xing'an Mountains of Northeast China. Chin. J. Ecol. 2013, 32, 2837-2843. (In Chinese with English abstract) 
90. Gu, H.Y.; Jin, J.B.; Chen, X.W.; Wang, E.H.; Zou, Y.Y.; Chai, Y.F. The Long-term impacts on chemical properties of Larix gmelini forest on the northern slope of Greater Xing'an Mountains from a forest fire of varying fire intensity. J. Nat. Resour. 2010, 25, 1114-1121. (In Chinese with English abstract)

91. Hernández, T.; García, C.; Reinhardt, I. Short-term effect of wildfire on the chemical, biochemical and microbiological properties of Mediterranean pine forest soils. Biol. Fer. Soils 1997, 25, 109-116.

92. Nannipieri, P.; Nuccini, L.; Ciardi, C. Microbial biomass and enzyme activities: Production and persistence. Soil Biol. Biochem. 1983, 15, 679-685.

93. Kandeler, E.; Eder, G. Effect of cattle slurry in grasslands on microbial biomass and on activities of various enzymes. Soil Biol. Biochem. 1993, 16, 249-254.

94. Waldrop, M.P.; Zak, D.R.; Sinsabaugh, R.L.; Gallo, M.; Lauber, C. Nitrogen deposition modifies soil carbon storage through changes in microbial enzymatic activity. Ecol. Appl. 2004, 14, 1172-1177.

95. Dale, V.H.; Joyce, L.A.; McNulty, S.; Neilson, R.P.; Ayres, M.P.; Flannigan, M.D.; Hanson, P.J.; Irland, L.C.; Lugo, A.E.; Peterson, C.J.; Simberloff, D.; Swanson, F.J.; Stocks, B.J.; Wotton, B.M. Climate change and forest disturbances. BioScience 2001, 51, 723-734.

(C) 2014 by the authors; licensee MDPI, Basel, Switzerland. This article is an open access article distributed under the terms and conditions of the Creative Commons Attribution license (http://creativecommons.org/licenses/by/4.0/). 